\begin{tabular}{|c|c|}
\hline \multicolumn{2}{|r|}{ About the Journal } \\
\hline Journal DOI & https://doi.org/10.21659/rupkatha \\
\hline Journal Home & www.rupkatha.com $\oslash$ \\
\hline Indexed by & 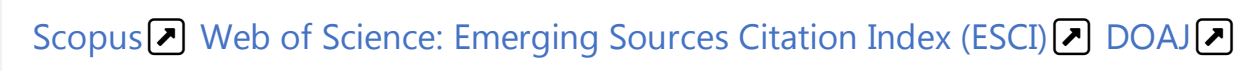 \\
\hline Journal Metrics & CiteScore 2020: 0.2 | SJR 2020: 0.162 | SNIP 2020: 0.193 | JCI 2020: 0.50 \\
\hline \multicolumn{2}{|r|}{ About the Issue } \\
\hline Themed issue & $\begin{array}{l}\text { Volume 4, number 1, } 2022 \text { (January-March) | Contemporary East and } \\
\text { Southeast Asian Literary and Cultural Studies }\end{array}$ \\
\hline Guest Editors & Dr Jeremy de Chavez $\oslash \&$ Dr Zhang Yue, University of Macau, China \\
\hline Issue DOI & https://doi.org/10.21659/rupkatha.v14n1 \\
\hline TOC & https://rupkatha.com/v14n1.php \\
\hline Peer Review & Under the responsibility of the Guest Editors \\
\hline \multicolumn{2}{|r|}{ About the Article } \\
\hline Title & Bagay. Articulating a New Materialism from the Philippine Tropics \\
\hline Author/s & Christian Jil R. Benitez $\bowtie$ \\
\hline Affiliation & Department of Filipino, Ateneo de Manila University, Quezon City, Philippines \\
\hline Author ID & https://orcid.org/0000-0002-0654-1698 \\
\hline Funding & No funding received. Published free of any charge. \\
\hline Article DOI & https://doi.org/10.21659/rupkatha.v14n1.07 Pages: 1-11 \\
\hline Abstract & https://rupkatha.com/v14n107 Ø \\
\hline Full-text PDF & https://rupkatha.com/V14/n1/v14n107.pdf Ø \\
\hline \multirow[t]{3}{*}{ Article History } & Abstract received: 31 March 2021 | Complete article received: 30 May 2021 \\
\hline & Revised article received: 29 August 2021 | Accepted:30 August 2021 \\
\hline & First Published: 05 February 2022 \\
\hline Article Impact & Check Dynamic Impact \\
\hline Copyright & Aesthetics Media Services $\square$ \\
\hline Licensing & Creative Commons Attribution Non-Commercial $4.0 \triangle$ \\
\hline
\end{tabular}

This Open Access article is published under a Creative Commons Attribution Non-Commercial 4.0 International License (http://creativecommons.org/licenses/by-nc/4.0/), which permits non-commercial re-use, distribution, and reproduction in any medium, provided the original work is properly cited. For citation use the DOI. For commercial re-use, please contact editor@rupkatha.com. 
1 Rupkatha Journal, Vol. 14, No. 1, 2022

Research Article

\title{
Bagay: Articulating a New Materialism from the Philippine Tropics
}

\author{
Christian Jil R. Benitez \\ Department of Filipino, Ateneo de Manila University, Quezon City, Philippines
}

\begin{abstract}
Keeping in time with the new materialist turn that aspires to respond to the common disregard to matter in Euro-Western tradition of thought while at the same time insisting the imperative to decolonize such turn, this essay attempts to articulate a Philippine rendition of new materialism, through the notion of bagay, nominated here as a thing whose materiality is intuited to be appropriately determinable concerning a particular moment. This attempt is extended through turning to Bagay poetry, "a concept, a proposition" (Lumbera 2005, 136) from the 1960s toward a Philippine poetics that is most attuned to the concreteness of things, instead of simply overlooking them-a disregarding impulse that is primarily attributed to the "platitudinous and emotional tendencies" ("Bagay Poets" 1965, 24) in Philippine poetry at the time which considers things as mere metaphors, if not symbols for anthropocentric sentimentalizations. Through harnessing then an attentiveness on things encouraged by the Bagay poetics, the materiality of bagay is then sensed in its utmost tropicality, that is, its capacity to turn into whatever.
\end{abstract}

Keywords: New materialism, bagay, Philippine poetics, decolonization, tropicality

\section{A new materialist imperative}

The recent new materialist turn in critical theory has allowed fundamental paradigmatic shifts in intellectual and social practices at large: as a conscious response to the "perceived neglect or diminishment of matter in the dominant Euro-Western tradition" of thought (Gamble et al. 2019, 111), new materialism has compelled many thinkers to reconsider how things, especially those that were often deemed as simply "non-living," participate in affairs that had been previously believed as exclusive for humans. Jane Bennett (2010), for instance, proposes that things partake in the most political of circumstances through what she nominates as the "vibrancy" of their materiality: as an "impersonal affect," she construes this vibrancy as "not a spiritual supplement or 'life force' added to the matter said to house it" but "a vitality intrinsic to materiality as such" (xiii; emphasis mine) that allows a given thing to interact with others, as to affect and be affected by them. With such "careful attentiveness" (17) on materiality, Bennett asserts then that the attempt toward a new materialist critique must only necessitate a foremost acknowledgement that things surrounding us humans are just as capable of affecting us as much as we do to them. In other words, it is to admit to one's essential "following," in the Derridean sense that "to be 
(anything, anyone) is always to be following (something, someone), always to be in response to call from something, however nonhuman it may be" (xiii; see also Derrida 2008).

This recognition of materialities as following one another is indeed instructive in rehearsing a new materialist critique, for the insight also reminds us that a new materialist intuition can only be similarly entangled, and thus "can be drawn from anywhere, anytime, and anyone," ultimately underscoring that "there is no limit to what practices, discourses, and artifacts... amenable" to this mode of ideation (Holbraad et al. 2014). However, as Zoe Todd (2016) tersely points out, if such were the case, "why is it not happening? Why is there still a bias towards citing white male scholars?" (17; see Ahmed 2014). This reflexive inquiry is most crucial as it intimates the possible "performative contradiction" between a purported new materialist practice and "the emphasis on the ethics and politics of social inquiry claimed as a promise of new materialist philosophy" (Rosiek et al. 2020, 332-333). In this sense, it only becomes an imperative that as much as new materialism responds to the aforementioned "neglect" and "diminishment" of matter in the "dominant Euro-Western" ideas, it must also take into account and eventually resist the comparable prevailing inattention-if not outright ignorance-to non-Euro-Western thinkings that might as well propose alternative manners by which materiality can be regarded. It is this imperative then that the present essay attempts to realize: to articulate, however preliminarily, what could be a Philippine rendition of a new materialist sensibility.

\section{A Philippine premise for a new materialism}

While the pronounced neglect of matter to which new materialism responds is often deemed as a consequence of the recent linguistic turn, if not "linguistic narcissism" (Barad 2007, 42; see also Barad 2003, 801), it is also critical to insist language, particularly in the form of words, as a material viable for initiating a new materialist critique (Ahmed 2008, 35-36). After all, words are also considerably "thick, living, physical objects that do unexpected things," as "irreducibly 'tropes' or figures... [that] can erupt or enliven things... trip us, make us swerve, turn us around..." (Haraway 2004, 200-201). This tropical or turning quality of words is especially true in their case in the Philippines, where words have been most intricately involved in the formation of the archipelago, not only in its discursive constructions as part of southeast Asia, the so-called Third-World, and the tropical zone, but also in the material facilitation of forces such as imperialisms that perpetually shape the country in the most concrete sense. For instance, the first dictionaries attending to the Philippine vernacular - the vocabularios on languages such as Tagalog, Bisaya, and Ilocano, among others (see Hidalgo 1977)—were borne out of colonial duress, primarily made by the Spanish friars as to assist their dissemination of the Catholic teachings and coercion of the natives into conversion; as such, the material life of words through and even beyond Spanish colonialism is ultimately mediated and co-operated by the vicissitudes of the said period. And yet, at the same time, the vibrant materiality of these words also offered the opportunities to eventually revolt against the Spanish imperial powers: as demonstrated by studies such as Rafael's (1988) and Ileto's (1979), it is also through certain words and their utmost tropicality that resistance has been imagined and rehearsed in time by the Filipino people. 
And so, words are most crucial, not only as "discursive entry points" (Benitez 2019, 459; see also Benitez 2017, 366-367) but as a viable material premise for a Philippine articulation of new materialism. It is then here that a Filipino rendition of the relevant signifiers matter, material, and thing becomes a critical point of departure: bagay, commonly understood as a noun, as in "anything that can be perceived by the five senses or conceived by the human mind, whether visible or not" ("anumang nadarama ng limang pandamdam o naaabot ng isip ng tao, nakikita man o hindi"), and can be "associated to uncertain meanings that usually refer to definitive cause, reason, significance, or value" ("ikinakapit... sa mga hindi tiyak na kahulugan na iniuukol kadalasan sa mga pakahulugang sanhi, dahilan, kabuluhan, o halaga") (Almario 2010, 101; translation mine). With its semantic malleability as being essentially "anything" ("anumán") or "whichever" ("alinmán") (Panganiban 1972, 94; translation mine), bagay can thus be easily extended to refer as well to a "circumstance, happening" ("pangyayari"), or an "example" ("halimbawa") (Santos 2019, 32). These latter definitions of what a bagay is are especially remarkable, for their implication appears to characterize the behaviour of the word bagayitself: considering its very tropicality, that is, the swerving quality that permits it to denote practically anything at any given time, an instance of bagay meaning something, in particular, can then only be a moment that is just as specific. Therefore, the thinghood of bagay-indeed, its pagkabagay-is intricately entangled to the temporal conditions-the "circumstance," the "happening"-in which such material is encountered (Benitez 2019, 477ff.).

Time as a rubric of the material in bagay can be further explored through considering the other definition of the vernacular term: as an adjective, bagay also refers to the quality of being "opportune" ("oportuno") (Serrano Laktaw 1914, 69; translation mine), or "what is done or happening in appropriate time, and when it is appropriate to do or happen" ("ang ginágawâ ó nangyáyari sa karampatang panahón, at kun kailán bágay na gawín ò mangyari") (Serrano Laktaw 1889, 416; translation mine). This kairotic quality is often expressed as being "fit, proper" of a particular matter, and thus stirring of the aesthetic, what "beautifies" ("nakagágandá") or "looks good on one" (Panganiban 1972, 94; translation mine). However, lest this aptness be mistaken as simply spontaneous or natural, an older definition of bagay reminds us that the implied coming together of materials is also an occurence facilitated by agencies at work: as defined in the $18^{\text {th }}$ century Vocabulario de la lengua tagala, bagay is also a verb, as in the gesture of "accommodating two things in a garment or in customs" ("acomodar... dos en el traje y costumbre"), just like in the imperative "Magbagay nang mang̃a batang magsasayao..." or "Group the children who will dance" (Noceda and Sanlúcar 2013, 38; translation mine). This acknowledgement of vibrancies actively gathering in bagay ultimately reconfigures then the common assumption of wholeness in a given material: if bagay is, say, "a form [or] a race" ("talle, casta"), it is only insofar as "different things, proportions" ("diferentes cosas, proporcion") (Noceda and Sanlúcar 2013, 38; translation mine) have been precedingly assembled to compose such, making its perceived singularity as a consequence of sedimentation over time (cf. Butler 1993, 9, in Ahmed 2008, 33).

Bagay, therefore, suggests a materiality that is most intimate with temporality: "while bagay can be anuman or anything that can be perceived by the senses, the anuman at hand can only be ascertained according to this bagay's appropriateness or timeliness to a particular moment" (Benitez 2019, 480). In other words, the vibrancy of bagay is that which emerges in and 
through time, taking into consideration the encounters in which it partakes at each instant: one thing can turn to-indeed, swerve as-something else in the next instant, contingent to the relationship it shares with other things, just as how even the sturdiest of materials-say, a stoneimaginably yields to transformation over time, due to its interaction with others-say, water. It is in this sense that bagay in its renditions in other Filipino languages can be similarly understood: in Bikolnon, for instance, bagayas referring to the virtue of "harmony" ("ugmâ") (Panganiban 1972, 95) can be recognized as ultimately emphasizing of the material assemblage always at work, including in the most seemingly absolute and desolate matter. It is also this virtue of synchronization that is intuited in Hiligaynon bagay, in its particular description of the term as "tuning [of] a musical instrument" ("apinasyó") (Panganiban 1972, 95), as to blend melodiously with others; and in Cebuano bagay, as a verse that is described as "similar to an enigmatic conversation that you have with another" ("como una conversacion enigmatica que se tiene con otro") (Encina 1804, 611; translation mine). In pagbabagay or gathering then of all these definitions, we can thus assert that a Philippine articulation of the new materialist sensibility, through the vernacular bagay, accentuates the inevitable entanglements one thing imparts with the surrounding others at any given time.

\section{Bagay poetry: a proposition}

The ideation of Philippine new materialism in the bagay can be further explicated via a poetic "proposition" ("panukala") (Lumbera 2005, 136; translation mine) that shares the same name: the Bagay poetry, which emerged in 1965, particularly from the Ateneo de Manila University-"a fortified stronghold of Americanized education for well-off Filipino youth" ("pinatibay na moog ng Amerikanisadong edukasyon para sa nakaririwasang kabataang Filipino")—as a response to the then prevalent attitudes and approaches in the university and in the country at large regarding poetry, including the "norm that English was the literary language of student writers" ("kalakarang Ingles ang wikang pampanitikan ng mga estudyanteng manunulat") (134; translation mine; see also Lumbera 2002, xiii; and Samar 2002). For the six initiating Bagay poets at the time-among them the eventual Philippine National Artists Rolando Tinio and Bienvenido Lumbera-a conscious turn to the vernacular was crucial considering their milieu, described as "a time when the country face[d] extreme nationalism and a search for national identity" ("Bagay Poets" 1965). However, this strategy did not necessarily mean for them a "reject[ion of] the foreign element which has permeated the native culture," for in fact, it is simultaneously "accepting [of] it," as to "explicate a contemporary picture... affirm[ing] the solidity which the cultural merging of the alien and the native has achieved" (emphasis mine).

Lumbera (2005), decades later, articulates the practical intentions of Bagay poetry, transposing the previously mentioned socially-involved motivations to the vocabulary of Philippine poetic traditions. According to him, Bagay poetry is ultimately "a proposition... on what they wanted to happen with Tagalog poetry" ("isang panukala... kung ano ang gusto naming mangyari sa tulang Tagalog"): that first, it "breaks free" ("humulagpos") from the "old" ("luma") tradition, with its "subjects submerged in emotionalism, and... oratory disposition" ("mga paksaing ibinabad sa emosyonalismo, at... astang orador"); and second, it "escapes" ("makatakas") from the "new" ("bago") tradition, or what he identifies as modernist poetry, which "barely attends to the 
readers due to complicated play with words and syntax of the English language, aside from the almost taciturn... theme" ("halos walang pakialam sa mambabasa dahil masalimuot ang paglalaro sa mga salita at sa sintaks ng wikang Ingles, bukod pa sa halos mapaglihim na... tema") (136; translation mine). ${ }^{1}$ It is in this sense that the most common features of Bagay poetry, namely "the use of concrete images and conversational language" ("Bagay Poets" 1965; see also Remoto 1984), can be further appreciated: these are deployed as to deliberately evoke the vernacular, however not in an imaginary that is artefactual and exotic, but instead most immediate, if not outright "realist" (Lumbera 1967, 358). As Lumbera (2005) also describes it, the locus of Bagay poetry is the proximate, its language as that which "has been heard... [for instance] in Tinio's residence in Gagalangin [in Tondo, Manila], and content... derived from the everyday lives of his family and neighbors" ("narinig na [halimbawa] sa... bahay [nina Tinio] sa Gagalangin, [at] nilalaman[g] hinango mula sa buhay-buhay ng kanyang pamilya at mga kapitbahay") (135-136; translation mine).

And yet, it is also crucial not to simply construe the poetics of Bagay as the mechanical rehearsal of these aforementioned tendencies. As Lumbera (2005) recounts, having attempted to write then a manifesto to "codify like laws" ("italang tila batas") what makes of a Bagay poem, his fellow Bagay poet Rolando Tinio objected, warning that such document would only limit their creative freedom as individual Bagay poets (12; translation mine) ${ }^{2}$ In lieu then of an outright, if not prescriptive, pronouncement, Tinio (2019) offered an articulation of the Bagay poetics through a poem, aptly titled "Bagay":

Sa harapan mo, nakatirik ang bagay

Sa gitna ng hanging halos gumagalaw.

Nagtitimpi. Sa pagkakahalukipkip

Lalo namang sumisidhi.

Nakatirik parang matang kamamatay.

Nakamulagat ma'y walang natatanaw.

Sinisipat ka nang buong kamangmangan.

Kay hina mong makiramdam!

Walang imik. Ano pa ang masasabi

Sa hanging bingi sa sariling paghuni?

Parang kimi. Bukas ang loob sa hubog

$\mathrm{Ng}$ araw na sumasaklob.

At sa iyo (wala nang biruan ito)

Tigas pa ring naghihintay.

Baka raw sakaling kung magkasubuan,

Sukat sinuhin, tuntunin,

Bigyan ng pangalan kung maari rin lang.

$(12$, qtd. in Lumbera 2005, 12)
Before you, the bagay stands

Amid the almost changing air.

Holding back. In restraint

It only grows grave.

Standing like an eye that just died

Open yet nothing in sight

Inspecting you unknowingly.

How insensitive can you be!

Without a sound. What else can be said

To the wind deaf to its own whistle?

Seems timid. Vulnerable to the shape

Of the sun that shelters.

And to you (there's no joking now)

A hardness that still awaits.

That maybe, worst comes to worst,

It just might be known, probed,

Given a name if possible.

(translation mine)

According to Lumbera (2005), Tinio's "Bagay" is an imperative for a poet to "be intimate... with the physicality of the world" ("[maki]pagtalik... sa pisikalidad ng mundo"), a gesture that could yield a 
poem that "neither orates nor sermons [but] 'vulnerable to the shape / of the sun that shelters'" ("hindi nagtatalumpati o nagsisermon, 'bukas ang loob sa hubog / ng araw na sumasaklob'" (12; translation mine). In other words, for the Bagay poets, the moment of creation is claimed to be instigated by an encounter with the things that surround us, provided that one is most willing to be vulnerable enough as to perceive and realize how these materials affect us-or at the very least, "await" us, in their vibrant ways, to finally interact with them. It might as well be a vulnerability that admits to one's present incapacity to understand their entanglement with the material world at large if only to let "discourse itself... unfold, and possibly again" (Benitez 2021b, 76). In this sense, similar to other renditions of new materialism as conceived in various contexts, the poetics of Bagay thus aspires for a careful attentiveness even to the most seemingly inert of things. And in the case of Bagay poetry, what bears further emphasis is how it particularly imagines the said attentiveness to be initiating as well of a possible generative instant-as indeed to be giving way to a poem, or at the very least, after "knowing," "probing," or perhaps even "naming" the material encountered, to another understanding of it. $^{3}$

Therefore, what Bagay poetry particularly adds to the present attempt to articulate new materialism from the Philippine vernacular bagay is its emphasis on another implication of our most material entanglements: that these intimacies, in themselves, create other materials as well, such as a poem, that in turn will be encountered by others. This way, Bagay poetry is instructive as a crucial reminder that as much as we are inevitably "following" or "responding" to some other matter, other matters are also always - and already_-"following" us. There is then a perceptible perpetual excess here, not only in the sense that the bagay in its indeterminacy is capable of becoming anything at any given moment but also in the sense that no matter how singular it may appear, the bagay is always already enmeshed in an assemblage with others, a gathering that further proliferates, most tropical or turning to the extent that one "no longer know[s]... who comes before and who is after whom" (Derrida 2008, 10). And to recognize one's complicity in such assemblage, and to maybe articulate its experience in a poem, what one only needs to doas Tinio (2019) writes in one of his ars poetica, simply called "Sa Poetry" ("On Poetry") —is to "let things take shape":

[M]agsilid ng hangin sa buslo, dumukot,

By golly, see what you've got-

Bouquet of african daisies,

Kabit-kabit na kerchief,

Kung swerte pa, a couple of pigeons,

Huhulagpos, beblend sa katernong horizon,

You can't say na kung saan hahapon.

(90)
Fill a basket with air, then draw,

By golly, see what you've got-

Bouquet of African daisies,

Knotted handkerchiefs,

And if lucky, a couple of pigeons,

Flying, blending to the matching horizon

You can't say anymore where they'd perch.

(translation mine) 


\section{A tropical materiality}

As attempted in the present essay, a Philippine articulation of new materialism through the vernacular notion of bagay is thus as follows: things, in their materiality, are intuited to be intricately entangled with time itself, as it is with and through the latter that the former can be perceived, if only for a moment. It is this interwovenness between the material and the temporal that is ultimately recognized and underscored in the eponymous poetics of Bagay, with its particular attention on the concrete and the quotidian. At the same time, with its primary imperative of "becoming intimate with the physicality of the world," as to possibly "know," "probe," or "name" the things that surround us, the poetics of Bagay also emphasizes the generative possibility in any instance of encounter with materials, with its chance to yield another material such as a poem or a semblance of understanding in the process. This way, new materialism as refracted through the vernacular bagay intimates of a Philippine world that is most bountiful in terms of material relations: things, including us humans, are sensed to be always already influxes with other things, constantly affecting and being affected by them one way or another. Such coalescences involve even the most seemingly singular of materials among us, for as the Bagay poet Tinio (2019) also imagines, these things can only be "wearing... a form /... that is a veil made of all things - / All things it is not" ("[n]agsusuot... ng anyong /.... lambong na yari sa lahat- / Lahat ng di-[ito]") (186; translation mine). Any single bagay, in other words, is already a multiplicity, an abundance: an assemblage of perhaps many other bagay.

It is from this acknowledged entanglement of things that the material world, as understood from the Philippine vernacular, can be perceived as most tropical, however not in its commonly exoticised sense as "paradisical, luxuriant and redemptive, but also primaeval, pestilential and debilitating" (Clayton 2012, 180), but in its demonstration of a behaviour that resonates to the very etymology of the said word: from the Greek trópos, meaning a "turn," as in "to swerve, not to get directly somewhere" (Haraway 2004, 201), and at the same time, recognizing that each veering instant is "always not only a deviation from... but also a deviation towards..." (White 1986, 2). In other words, this attribution underscores how the bagay is ultimately "ambivalent" (Jacobo 2011, 22) in terms of its orientations: the bagay is tropical insofar as it is indeterminable, capable as it is of turning in/to practically whatever, so long as its most immediate milieu would permit—or even necessitate-such version of its thinghood. By this virtue, the material that is the bagay can be regarded as most adaptive, if not appropriating to any given instant: it is always nakikibagay, and thus can become a wide array of things-polytropic indeed, with its "temporary... [and] plural... sympathies" (Flores 2014, 61). It is this tropicality of the bagay that Tinio (2019) himself also intuits in his "Mga Ehersisyong Analitiko" ("Analytic Exercises"), when he asserts the world as "the wholeness of what happens... [With] the bagay [as] the never / possibly happening" ("ang kabuuan ng mga nagaganap... / [At] ang mga bagay [bilang] mga hindi / na maaaring maganap") (183; translation mine).

This worldly implication of the bagay is most crucial, for it reminds us that tropicality, while indeed an "attitude" of things, simultaneously evokes the material "worldly zone" that shapes and is shaped by the same things, in which the Philippine archipelago geographically belongs (Jacobo $2011,22)$. And in the case of the present attempt to articulate a new materialism from "the sign of the Philippine," the locatedness of this endeavor does not only "enclose" it in this particular 
"geopolitical reality," but also "open [it] up" (23) to the imperative of further "knowing," "probing," and "naming" the notion of the material within the wider milieu that is the tropics itself. Specifically in the context of Southeast Asia, this new materialist rumination on the Philippine signifier bagay can only evoke similar reconsiderations on its cognates, for instance, the Malay bagai, meaning "kind, variety, species"; the Toba Batak bage, meaning "various"; and the Acehnese bagofë, meaning "sort, kind, manner" or "just like, identical to" (Blust and Trussel 2020)—all of which can be traced back to the Tamil vakai (வகை), whose definitions include "division," as in a "caste" or "kind"; "manner" and "ways"; and "nature" and "quality" (University of Madras 1936). Therefore, just as how the notion of the bagay intimates materiality to be always multiple, in assemblage with other things, however singular an instance of it might appear, the sign of the bagayeffectively "widen[s] the latitude of the Philippine," swerving it as to underscore its being a "part of the SouthEast Asian relay of relations" (Flores 2014, 62).

Through the tropicality of the bagay-including the word bagay itself-the Derridean "following" of the Philippines at large can thus be only given prominence, accentuating how it perpetually answers to the call of the world itself, with the most seemingly inert of things among such chorus. This "relationality" is crucial, for not only does it simply "imbricate" the Philippines within the "system" that is the world, but also proposes the possibility of "intimating" such system "in pieces, like islands in an archipelago" (Flores 2014, 52)—and particularly as the Philippine archipelago, however briefly from certain slants of light. In other words, it is perhaps the world itself through its spheroid shape becoming critically instructive: without any vertex as an apparent point of origin for circumnavigation, any locale or instance can thus be similarly nominated as a viable ground to initiate a world-encompassing discourse (Benitez 2021a, 6). Might as well begin then with what is before us at any given time: the bagay standing, awaiting still.

\section{Declaration of Conflict of Interests}

The author(s) declared no potential conflicts of interest.

\section{Funding}

No funding has been received for the publication of this article. It is published free of any charge.

\section{Endnotes}

This essay was developed and written through the support of a University Research Council (URC) Standard Grant from the Ateneo de Manila University, for which the author expresses his utmost gratitude.

${ }^{1}$ Lumbera's transposition of the motives of Bagay poetry is crucially retrospective, as suggested by his use of categories of "old" and "new" traditions, which seamlessly corresponds to, if not outright derives from, Virgilio Almario's (1984) eventual major classifications of Philippine poetry, namely the tradition he calls Balagtasism and Modernism, which he explicates through a historiography of poems from the Spanish colonial period up to the contemporary period. In Almario's typology, however, contrary to Lumbera'sand presumably, all the Bagay poet's-resistance, Bagay poetry is classified under the modernist tradition, described as "inward" ("paloob") in orientation, in the sense that it has a "private purpose [that] causes 
various degrees of 'ambiguity' for the masses accustomed to old subjects and rhetorical tools of outward poetry [that is, Balagtasist poetry]" ("pribadong layunin [na] nagdudulot ng iba't ibang antas ng 'kalabuan' para sa madlang namihasa sa lumang paksain at kasangkapang panretorika ng tulang palabas") (15).

2 Curiously, Almario (1984) includes in his historical study a five-point "unpublished declaration" ("dinailathalang pahayag") purportedly from the Bagay poets, that lists the following defining characteristics of their poetry: (1) rouses a "new understanding" ("bagong pagkaunawa") of bagay; (2) invokes an "imagery that is realistic, different, and precise in structure" ("pangitaing makatotohanan, kaiba, at walang-labiswalang-kulang ang pagkakabanghay"); (3) describes in a manner that is "retraint yet faithful to complexity of ideas and emotions" ("matimpi ngunit matapat sa kasalimuutan ng kaisipa't damdamin"); (4) utilizes the vernacular as how it is articulated in the present; and (5) "regards... a particular addressee, and not the entire humanity, the universe, or other grand abstractions" ("patungkol... sa isang tiyak na kausap, hindi patungkol sa sangkatauhan, sandaigdigan, at iba pang sangkakuwanan") (204-205).

${ }^{3}$ For Tinio (2019), ideations are also material, imagined as dormant words residing in one's consciousness, waiting to be transformed-indeed, materialized-as a poem:

Sa loob na loob ng kamalayan mo,

May mga katagang naghihintay lamang

Hugutin, taliman,

Upang mataluntong kahit mapasaan

Ang bawat kurbatura ng pakiramdam. (190)

In your innermost consciousness,

There are words simply waiting

To be drawn, sharpened,

To discover wherever they may go

Each curvature of sensations. (translation mine)

\section{References}

Ahmed, S. (2008). "Open Forum Imaginary Prohibitions: Some Preliminary Remarks on the Founding Gestures of the 'New Materialism.'" European Journal of Women's Studies, 15(1): 23-39. DOI: $10.1177 / 1350506807084854$

Ahmed, S. (2014, November 4). White Men. Feminist Killjoys Blog. https://feministkilljoys.com/2014/11/04/white-men/

Almario, V. (1984). Balagtasismo Versus Modernismo: Panulaang Tagalog sa Ika-20 Siglo. Ateneo de Manila University Press.

Almario, V. (Ed.). (2010). UP Diksyonaryong Filipino (rev. ed.). Sentro ng Wikang Filipino, University of the Philippines.

"Bagay Poets." (1965). Heights, 14(1): 24.

Barad, K. (2007). Meeting the Universe Halfway: Quantum Physics and the Entanglement of Matter and Meaning. Duke University Press.

Barad, K. (2003). "Posthumanist Performativity: Toward an Understanding of How Matter Comes to Matter." Signs, 28(3): 801-831. DOI: 10.1086/345321

Benitez, C. J. R. (2017). "Tungo sa Dalumat ng Bayan: Isang Metonimiya." Kritika Kultura, 29: 363-385. DOI: 10.13185/KK2017.02917 
Benitez, C. J. R. (2019). "Panahon and Bagay: Metonymy and the Close Reading of Dictionaries to Understand Filipino Temporality." Philippine Studies, 67(3-4): 457-488. DOI: 10.1353/phs.2019.0023

Benitez, C. J. R. (2021a). "1521| 2021." Katipunan, 7: 4-6. https://ajol.ateneo.edu/katipunan/articles/234/2568

Benitez, C. J. R. (2021b). "Telepathic Visions: On Alvin Yapan's An Kubo sa Kawayanan (2015)." Res Rhetorica, 8(2): 55-81. DOI: 10.29107/rr2021.2.4

Bennett, J. (2010). Vibrant Matter: A Political Ecology of Things. Duke University Press.

Butler, J. (1993). Bodies That Matter: On the Discursive Limits of Sex. Routledge.

Blust, R. \& Trussel, S. (2020). Various, suitable, equal. In The Austronesian comparative dictionary. Retrieved 29 August, 2021, from https://www.trussel2.com/acd/acd-lo_v.htm\#var

Clayton, D. (2013). "Militant tropicality: war, revolution and the reconfiguration of 'the tropics' c.1940c.1975." Transactions of the Institute of British Geographers, 38(1): 180-192. DOI: 10.1111/j.14755661.2012.00510.x

Derrida, J. (2008). The Animal That Therefore I Am (M. L. Mallet, Ed.). Fordham University Press.

Encina, F. (1804). Arte de la lengua Zebuana. J. T. Medina.

Flores, P. (2014). Philippine Polytropic: Intimating the World in Pieces. In Antoinette M. \& Turner C. (Eds.), Contemporary Asian Art and Exhibitions: Connectivities and World-making (pp. 47-66). ANU Press.

Gamble, C. N., Hanan, J. S., \& Nail, T. (2019). "What is New Materialism?." Angelaki, 24(6): 111-134. DOI: 10.1080/0969725X.2019.1684704

Haraway, D. (2004). The Haraway Reader. Routledge.

Hidalgo, C. A. (1977). Philippine lexicography from 1521 to the present. University of the Philippines. Holbraad, M., Pedersen, M. A., \& Viveiros de Castro, E. (2014, January 19). The Politics of Ontology: Anthropological Positions. Fieldsights. https://culanth.org/fieldsights/the-politics-of-ontologyanthropological-positions

Ileto, R. C. (1979). Pasyon and Revolution: Popular Movements in the Philippines, 1840-1910. Ateneo de Manila University Press.

Jacobo, J. (2011). Mood of Metaphor: Tropicality and Time in the Philippine Poetic (Publication No. 3473849) [Doctoral dissertation, State University of New York - Stony Brook]. ProQuest Dissertations Publishing.

Lumbera, B. L. (1967). "The Folk Tradition of Tagalog Poetry." In A. Manuud (Ed.), Brown Heritage: Essays on Philippine Cultural Tradition and Literature (pp. 331-360). Ateneo de Manila University Press.

Lumbera, B. L. (2002). Balaybay: Mga Tulang Lunót at Manibalang. Talindao Publishing House.

Lumbera, B. L. (2005). Bayan at Lipunan: Ang Kritisismo ni Bienvenido L. Lumbera (R. Torres-Yu, Ed.). University of Sto. Tomas Publishing House.

de Noceda, J., \& de Sanlúcar, P. (2013). Vocabulario de la lengua tagala (V. S. Almario, E. R. Ebreo, \& A. M. M. Yglopaz, Eds.; E. R. Ebreo, A. M. M. Yglopaz, \& K. R. Santillan, Trans.). Komisyon sa Wikang Filipino. Panganiban, J. V. (1972). Diksyunaryo-Tesauro Pilipino-Ingles. Manlapaz Publishing Rafael, V. (1988). Contracting Colonialism: Translation and Christian Conversion in Tagalog Society under Early Spanish Rule. Ateneo de Manila University Press.

Remoto, D. R. (1984). "The Poetry of the Bagay Movement." Heights 31(2): 1-8. 
Rosiek, J. L., Snyder, J., \& Pratt, S. L. (2020). "The New Materialisms and Indigenous Theories of NonHuman Agency: Making the Case for Respectful Anti-Colonial Engagement." Qualitative Inquiry, 26(34): 331-346. DOI: $10.1177 / 1077800419830135$

Samar, E. (2002). "Sa Paligid ng Bagay: Ang Konteksto sa Pag-usbong ng Tulang Pilipino sa Ateneo, 19651969." The Loyola Schools Review: School of Humanities, 1(3): 135-156.

Santos, V. C. (Ed.). (2019). Vicassan't Pilipino-English Dictionary (new abridged ed.). Anvil Publishing, Inc. Serrano Laktaw, P. (1889). Diccionario Hispano-Tagalog. Estab. Tipográfico "La Opinión" á cargo de G. Bautista.

Serrano Laktaw, P. (1914). Diccionario Tagalog-Hispano. Imp. y Lit. de Santos y Bernal. Todd, Z. (2016). "An Indigenous Feminist's Take On The Ontological Turn: 'Ontology' Is Just Another Word For Colonialism." Journal of Historical Sociology, 29(1): 4-22. DOI: 10.1111/johs.12124 University of Madras. (1936). வகை vakai. In Tamil lexicon (p. 3450). Diocesan Press.

White, H. (1978). Tropics of Discourse: Essays in Cultural Criticism. John Hopkins University Press.

\section{Author's bio-note}

Christian Jil R. Benitez teaches Filipino at Ateneo de Manila University, where he obtained an AB-MA in Filipino literature (2016/2018). Hailed as Poet of the Year 2018 by the Commission on the Filipino Language, his critical and creative works on time, tropicality, and mythology have appeared in Katipunan, Kritika Kultura, Philippine Studies, eTropic, and Res Rhetorica, among others. He lives in Rizal, Philippines. 